\title{
Oviposition and egg quality traits of dwarf and naked neck layers
}

\author{
A. Garcês ${ }^{1, \#}$ and N.H. Casey ${ }^{2}$ \\ ${ }^{1}$ Veterinary Faculty, Eduardo Mondlane University, C.P. 3670, Maputo, Mozambique \\ ${ }^{2}$ Department of Animal \& Wildlife Sciences, University of Pretoria, Pretoria 0002, South Africa
}

\begin{abstract}
Oviposition and egg quality traits were studied in dwarf and naked neck layers in Maputo (Mozambique) during a 28-d period at 35 weeks of age. Birds were caged individually in a laying house with natural light and ventilation. Average daylight length during the study was $11.2 \mathrm{hr}$ and minimum and maximum temperature was $19.6{ }^{\circ} \mathrm{C}$ and $30.1{ }^{\circ} \mathrm{C}$, respectively. The main results show that the sex-linked dwarfing gene $(d w)$ increased the mean interval and time of oviposition, and reduced the sequence length and rate of lay. A bimodal distribution of oviposition intervals was observed in the dwarf population. No meaningful effect of the naked neck $(\mathrm{Na})$ gene could be seen on oviposition traits. The $d w$ gene also reduced the egg and components weight as well as the height of the albumen. The $\mathrm{Na}$ gene was associated with increased yolk weight and reduced albumen height.
\end{abstract}

Keywords: Naked neck, dwarf, oviposition, egg quality, laying hens

${ }^{\#}$ Corresponding author. E-mail: rgarces@tvcabo.co.mz

\section{Introduction}

The dwarf $(d w)$ and naked neck $(N a)$ genes in poultry contribute diversely, but inconclusively to production traits and environmental adaptability. The effect of the $d w$ gene on egg characteristics reported in literature is not entirely consistent. In comparison with the normal sized counterparts, albumen height of dwarfs was either similar (Horst \& Petersen, 1981) or increased (Mérat, 1971), breaking strength in hot environment was found to be either similar (Horst \& Petersen, 1981) or higher (Mukherjee et al., 1986), and shell thickness was reported to be higher (Amin-Backche \& Mérat, 1975) or similar (Mérat, 1972). No significant effect of the naked neck gene on egg quality traits has been reported, though the combination of the $N a$ and the $d w$ genes was associated with decreased shell breaking strength (Katangole et al., 1990). The naked neck $(\mathrm{Na})$ genes improved biological efficiency and productivity, but none of the feather-reducing genes significantly improved egg production or feed efficiency, while the dwarf gene $(d w)$ was associated with delayed sexual maturity, production of fewer and lighter eggs, higher persistence, better feed conversion and higher survivability (Garcês et al., 2001).

The sex-linked dwarfing gene reduces vittelogenesis, increases oviposition interval and shortens sequence length (Yoo et al., 1984). Accordingly, both egg production and egg weight are consistently reduced, although the expression response of the dwarf gene is influenced by a specific interaction with the background genome (Reddy \& Seigel, 1977). The naked neck gene has been associated with increased laying rate, egg size and egg mass in hot environments, the effects on these traits being more modest in temperate climates (Horst \& Rauen, 1986). The association of both genes seems advantageous even in moderately warm environments since efficiency is improved and egg weight is increased relative to the normal feathered genotype (Mérat, 1990).

This paper reports the effect of the two genes individually and their combined effect on oviposition and egg quality traits within sequences under the subtropical climatic conditions of Maputo.

\section{Materials and Methods}

Day old chicks were obtained from the Institute for Animal Basic Sciences of the Humboldt University of Berlin and transported to Maputo, Mozambique $\left(25^{\circ} 58^{\prime} \mathrm{S}, 32^{\circ} 35^{\prime} \mathrm{E}\right)$. The pullets were the offspring of a Dahlem Red commercial male line heterozygous for the naked neck $(\mathrm{Na})$ and dwarf $(d w)$ genes and a medium heavy commercial female line hemizygous for the normal alleles of the two genes. Four different genetic groups resulted from such mating plan as follows: 


\author{
Phenotypic specification \\ Normal feathered normal size \\ Normal feathered dwarf \\ Naked neck normal size \\ Naked neck dwarf
}

\author{
Genotypic classification \\ nana $D w$ - \\ nana $d w$ - \\ Nana Dw- \\ Nana $d w-$
}

Pullets were raised on floor under natural lighting with increasing photoperiod (August to December) and fed ad libitum standard commercial diets in a two-phase system. At 18 weeks they were moved to individual cages in a laying house with low sidewalls and wire netting to the roof and fed ad libitum a commercial diet containing $162 \mathrm{~g}$ of crude protein, $11 \mathrm{MJ} \mathrm{ME} / \mathrm{kg}, 36 \mathrm{~g}$ calcium and $6.4 \mathrm{~g}$ of phosphorus per $\mathrm{kg}$. Twenty-one layers of each genetic group with similar physiological ages (nana $D w-148.5 \pm 2.8 \mathrm{~d}$; Nana $D w-149.3 \pm 2.9 \mathrm{~d}$; nana $d w-146.8 \pm 3.1 \mathrm{~d}$; Nana $d w-145.7 \pm 2.5 \mathrm{~d}$ ) were used. The lighting was natural and the average length of daylight during the period studied was $11.2 \mathrm{hr}$. Minimum and maximum temperature was $19.6{ }^{\circ} \mathrm{C}$ and $30.1^{\circ} \mathrm{C}$, respectively, and relative humidity was $69 \%$.

Oviposition time, egg number and egg quality traits (whole egg, yolk and shell weights, albumen height, shell thickness and breaking strength) were measured during a 28-d period between 35 and 38 weeks of age, when production was high and stable (laying rate: normal size $85.4 \%$, dwarfs $66.5 \%$ ). Time of lay was recorded at hourly intervals from 06:00 to 18:00. Eggs were immediately weighed at the nearest $0.01 \mathrm{~g}$ and stored at $20{ }^{\circ} \mathrm{C}$ for quality evaluation on the following day. Breaking strength was measured with an appropriate device by applying a gradually increasing vertical force along the long axis of the egg. Eggs were broken out and components carefully separated. Shells were weighed fresh with membranes and allowed to dry at room temperature. Shell thickness excluding membranes was measured with a micrometer at two locations in the equatorial area. Egg quality was evaluated within complete sequences solely.

A sequence was defined, as a group of successive eggs separated by intervals not less than $37 \mathrm{hr}$ (Yoo et al., 1984). Total lag was calculated as the difference in time between the first and the last egg within a given sequence.

The genetic effect on the traits of interest in this study was investigated with one-way analysis of variance. Due to the asymmetry of the distribution of sequence length between body size groups, this trait was analysed with a Man-Whitney non-parametric test. The proportion of eggs laid in the morning and afternoon was compared with a chi-squared test. Linear regression was used to investigate the relationship between, (1) the mean oviposition interval and the sequence size, (2) the yolk and egg weights and the serial number of the egg within sequences. All statistics were computed by the use of SPSS/PC + procedures (Meyer, 1993).

\section{Results}

Oviposition traits by genetic group are summarized in Table 1 . The $d w$ gene increased the mean interval and time of oviposition $(\mathrm{P}<0.01)$, and reduced the sequence length and rate of lay $(\mathrm{P}<0.001)$.

Table 1 Oviposition traits by body size and feathering types, mean (s.e.m.)

\begin{tabular}{|c|c|c|c|c|c|c|c|}
\hline \multirow{2}{*}{$\begin{array}{l}\text { Body size type } \\
\text { Feathering type }\end{array}$} & \multicolumn{2}{|c|}{$d w-$} & \multicolumn{2}{|c|}{$D w-$} & \multicolumn{3}{|c|}{ Significance of effects } \\
\hline & Nana & nana & Nana & nana & $\mathrm{Na}$ & $D w$ & $N a \times d w$ \\
\hline Mean oviposition interval, hr & $\begin{array}{l}28.1 \\
(0.13)\end{array}$ & $\begin{array}{c}27.7 \\
(0.17)\end{array}$ & $\begin{array}{c}26.3 \\
(0.18)\end{array}$ & $\begin{array}{l}26.0 \\
(0.13)\end{array}$ & $\mathrm{NS}^{1}$ & $* * *$ & NS \\
\hline Mean oviposition time, $\mathrm{hr}$ & $\begin{array}{c}11.2 \\
(0.09)\end{array}$ & $\begin{array}{l}10.9 \\
(0.09)\end{array}$ & $\begin{array}{l}10.5 \\
(0.11)\end{array}$ & $\begin{array}{l}10.5 \\
(0.11)\end{array}$ & NS & $* *$ & NS \\
\hline Inter-sequence interval, hr & $\begin{array}{c}47.3 \\
(1.40)\end{array}$ & $\begin{array}{c}47.9 \\
(1.22)\end{array}$ & $\begin{array}{c}44.5 \\
(1.31)\end{array}$ & $\begin{array}{c}45.0 \\
(1.71)\end{array}$ & NS & $*$ & NS \\
\hline Total lag, hr & $\begin{array}{c}5.78 \\
(0.17)\end{array}$ & $\begin{array}{c}5.94 \\
(0.17)\end{array}$ & $\begin{array}{c}6.32 \\
(0.25)\end{array}$ & $\begin{array}{c}6.02 \\
(0.35)\end{array}$ & NS & NS & NS \\
\hline Sequence length, eggs & $\begin{array}{c}2.38 \\
(0.10)\end{array}$ & $\begin{array}{c}2.62 \\
(0.14)\end{array}$ & $\begin{array}{c}7.15 \\
(0.66)\end{array}$ & $\begin{array}{c}6.75 \\
(0.69)\end{array}$ & NS & $* * *$ & NS \\
\hline Hen-day production, $\%$ & $\begin{array}{c}64.5 \\
(3.49)\end{array}$ & $\begin{array}{c}67.4 \\
(3.12)\end{array}$ & $\begin{array}{c}84.1 \\
(2.31)\end{array}$ & $\begin{array}{c}80.1 \\
(3.66)\end{array}$ & NS & $* * *$ & NS \\
\hline
\end{tabular}

${ }^{1} \mathrm{NS}=$ Not significant; $* \mathrm{P}<0.05 ; * * \mathrm{P}<0.01 ; * * * \mathrm{P}<0.001$ 
Table 2 shows oviposition intervals by sequence length and the respective regression coefficients. Dwarf pullets in comparison with the normal size counterparts had longer intervals between successive eggs laid in short sequences of two and three eggs $(\mathrm{P}<0.05)$, the differences becoming negligible in longer sequences. Oviposition intervals were inversely associated with the size of the sequence in both body size groups $(\mathrm{P}<0.001)$, approaching $24 \mathrm{hr}$ in moderate or long sequences.

Table 2 Mean oviposition interval according to the length of the sequence (s.e.m)

\begin{tabular}{|c|c|c|c|c|c|}
\hline \multirow{2}{*}{$\begin{array}{l}\text { Body size } \\
\text { Type }\end{array}$} & \multirow{2}{*}{$\begin{array}{l}\text { Feathering } \\
\text { type }\end{array}$} & \multicolumn{4}{|c|}{ Sequence length } \\
\hline & & 2 & 3 & 4 & $5+$ \\
\hline \multirow[t]{2}{*}{$d w-$} & Nana & $29.1(0.10)$ & $27.3(0.10)$ & $26.2(0.11)$ & $25.4(0.16)$ \\
\hline & nana & $29.2(0.18)$ & $27.1(0.12)$ & $26.4(0.08)$ & $25.4(0.08)$ \\
\hline \multirow[t]{2}{*}{$D w-$} & Nana & $28.5(0.24)$ & $26.7(0.21)$ & $26.1(0.12)$ & $25.2(0.08)$ \\
\hline & nana & $28.7(0.33)$ & $26.6(0.15)$ & $26.2(0.08)$ & $25.4(0.12)$ \\
\hline \multirow{2}{*}{$\begin{array}{l}\text { Difference } \\
d w-D w\end{array}$} & Nana & $*$ & $* *$ & NS & NS \\
\hline & nana & $*$ & $*$ & NS & NS \\
\hline \multicolumn{6}{|c|}{ Regression equations of mean oviposition interval on sequence length: } \\
\hline \multicolumn{3}{|l|}{ Dwarf population: } & \multicolumn{3}{|c|}{ Normal size population: } \\
\hline$Y=23.39+\frac{11.53}{x}$ & \multicolumn{2}{|c|}{$\left(\mathrm{R}^{2}=0.76 ; \mathrm{P}<0.001\right)$} & \multicolumn{3}{|c|}{$\mathrm{Y}=23.89+\frac{8.83}{\mathrm{x}}\left(\mathrm{R}^{2}=0.80 ; \mathrm{P}<0.001\right)$} \\
\hline
\end{tabular}

Figure 1 displays the distribution of oviposition intervals in each genetic group. It is worth noting that unlike the normal sized, dwarf hens showed distinct peaks at 25 and $29 \mathrm{hr}$. Accordingly, they laid 80\% more eggs $(\mathrm{P}<0.01)$ in the afternoon than the normal counterparts (data not shown).

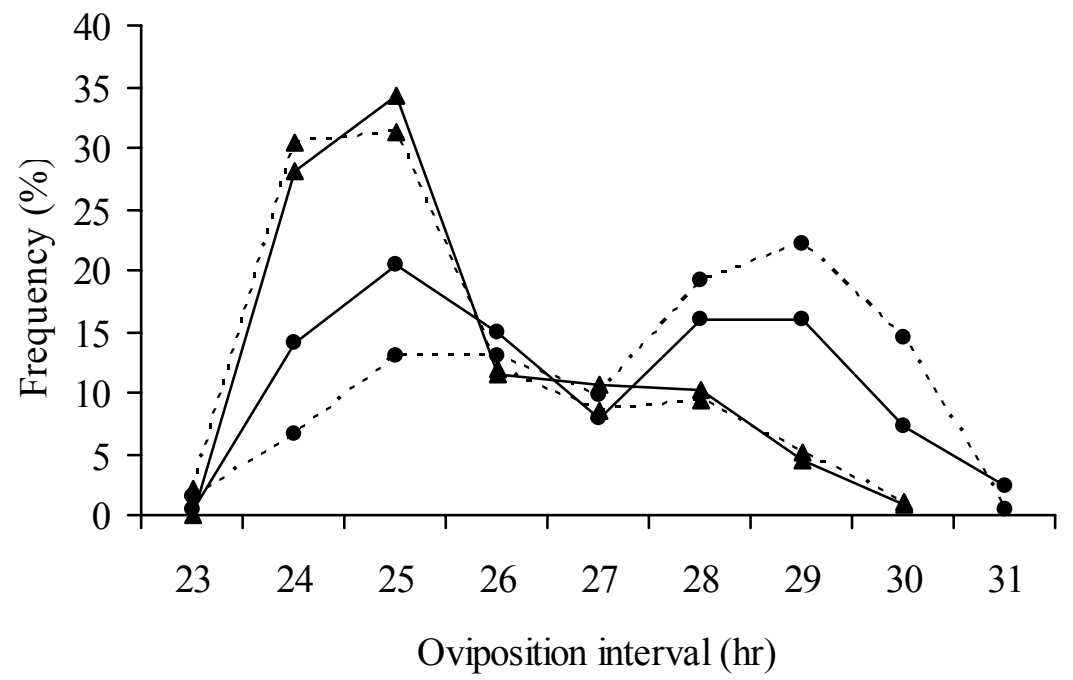

Figure 1 Frequency distribution of time intervals between successive eggs within sequences (normal size $\mathbf{\Lambda}$, dwarf $\bullet$; normal neck - , naked neck ----)

Mean oviposition interval was positively correlated with both mean time of lay and inter-sequence interval (Table 3). A high negative correlation was found between oviposition interval and egg number. The correlation between oviposition interval and egg weight yielded negative values in the naked neck normal size hens and positive though weak in the remaining groups.

Egg and yolk weights were regressed on the position of the egg within the sequence and the results are presented in Table 4. It is worth noting that coefficients were negative $(\mathrm{P}<0.05)$ for all genotypes and positive or nil for the naked neck normal size hens $(\mathrm{P}>0.05)$ and that egg weight declined throughout the sequence at a higher rate than that of the yolk. 
Table 3 Phenotypic correlation between mean oviposition interval and different traits

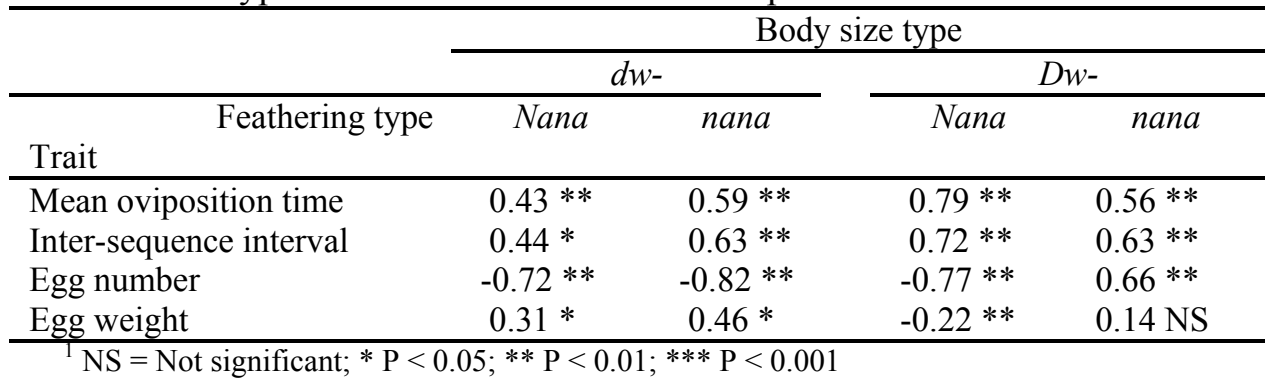

Table 4 Regression coefficients (s.e.m.) of egg and yolk weight on serial number of the egg

\begin{tabular}{cccc}
\hline \multirow{2}{*}{$\begin{array}{c}\text { Body size } \\
\text { type }\end{array}$} & $\begin{array}{c}\text { Feathering } \\
\text { type }\end{array}$ & \multicolumn{2}{c}{ Trait } \\
\cline { 2 - 4 }$d w-$ & Nana & $-1.36(0.54) *$ & $-0.14(0.19) *$ \\
& nana & $-1.95(0.23) * * *$ & $-0.29(0.05) * * *$ \\
& & & \\
& & $0.16(0.17) \mathrm{NS}$ & $-0.07(0.05) \mathrm{NS}$ \\
Nana & nana & $-0.77(0.11) * * *$ & $-0.26(0.04) * * *$ \\
\hline & ${ }^{1} \mathrm{NS}=$ Not significant; $* \mathrm{P}<0.05 ; * * \mathrm{P}<0.01 ; * * * \mathrm{P}<0.001$
\end{tabular}

Mean values for measured egg characteristics within the sequences are shown in Table 5. The data indicates that the dwarfing gene reduced the weights of the egg and its components as well as the height of the albumen $(\mathrm{P}<0.001)$. The $\mathrm{Na}$ gene was associated with increased yolk weight and reduced albumen height $(\mathrm{P}<0.001)$. Such decrease was more evident among the normal sized hens, as revealed by the interaction between the genes $(\mathrm{P}<0.01)$.

Table 5 Egg quality traits within sequences by body size and feathering types, mean (s.e.m.)

\begin{tabular}{|c|c|c|c|c|c|c|c|}
\hline \multirow{2}{*}{$\begin{array}{l}\text { Body size type } \\
\text { Feathering type }\end{array}$} & \multicolumn{2}{|c|}{$d w-$} & \multicolumn{2}{|c|}{$D w-$} & \multicolumn{3}{|c|}{ Significance of effects } \\
\hline & $\begin{array}{c}\text { Nana } \\
(\mathrm{n}=268)\end{array}$ & $\begin{array}{c}\text { nana } \\
(\mathrm{n}=213)\end{array}$ & $\begin{array}{c}\text { Nana } \\
(\mathrm{n}=286)\end{array}$ & $\begin{array}{c}\text { nana } \\
(\mathrm{n}=227)\end{array}$ & $\mathrm{Na}$ & $d w$ & $N a \times d w$ \\
\hline Egg weight, g & $\begin{array}{c}57.1 \\
(0.71)\end{array}$ & $\begin{array}{c}56.4 \\
(0.34)\end{array}$ & $\begin{array}{c}63.0 \\
(0.33)\end{array}$ & $\begin{array}{c}62.7 \\
(0.25)\end{array}$ & NS & $* * *$ & NS \\
\hline Yolk weight, g & $\begin{array}{c}15.3 \\
(0.21)\end{array}$ & $\begin{array}{c}14.9 \\
(0.07)\end{array}$ & $\begin{array}{c}16.7 \\
(0.09)\end{array}$ & $\begin{array}{c}16.1 \\
(0.07)\end{array}$ & $* * *$ & $* * *$ & NS \\
\hline Shell weight, $g$ & $\begin{array}{c}6.38 \\
(0.08)\end{array}$ & $\begin{array}{c}6.27 \\
(0.05)\end{array}$ & $\begin{array}{c}6.68 \\
(0.04)\end{array}$ & $\begin{array}{c}6.68 \\
(0.03)\end{array}$ & NS & $* * *$ & NS \\
\hline Albumen height, $\mathrm{mm}$ & $\begin{array}{c}6.81 \\
(0.18)\end{array}$ & $\begin{array}{c}6.83 \\
(0.05)\end{array}$ & $\begin{array}{c}6.91 \\
(0.08)\end{array}$ & $\begin{array}{c}7.30 \\
(0.06)\end{array}$ & $* * *$ & $* * *$ & $* *$ \\
\hline Shell thickness, $0.1 \mathrm{~mm}$ & $\begin{array}{c}3.87 \\
(0.04)\end{array}$ & $\begin{array}{c}3.85 \\
(0.02)\end{array}$ & $\begin{array}{c}3.82 \\
(0.03)\end{array}$ & $\begin{array}{c}3.85 \\
(0.02)\end{array}$ & NS & NS & NS \\
\hline Breaking strength, $\mathrm{kg}$ & $\begin{array}{c}2.74 \\
(0.08)\end{array}$ & $\begin{array}{c}2.70 \\
(0.04)\end{array}$ & $\begin{array}{c}2.72 \\
(0.05)\end{array}$ & $\begin{array}{c}2.82 \\
(0.04)\end{array}$ & NS & NS & NS \\
\hline
\end{tabular}

${ }^{\mathrm{T}} \mathrm{NS}=$ Not significant; $* \mathrm{P}<0.05 ; * * \mathrm{P}<0.01 ; * * * \mathrm{P}<0.001$

\section{Discussion}

The dwarfing gene caused an average elongation of $1.7 \mathrm{hr}$ on the mean interval between ovipositions. The magnitude of the effect was lower than that reported by Yoo et al. (1984). However, these authors introduced the $d w$ gene in strains already under selection for shorter oviposition interval, which could explain the difference. The increase in the mean time of oviposition and the reduction in sequence size and laying rate caused by the gene are in good agreement with previous research (Amin-Bakhche \& Merat, 1975).

Differences in oviposition intervals between the two body size groups could partly explain the lower laying rate of dwarfs (-14.2\%). In fact, the Morris equation for a 24-hr cycle (Morris, 1973; [equation 4]) applied to the mean oviposition interval and total lag observed in this study, predicts the difference between the laying rates of dwarfs and normal sized hens to be $8.6 \%$. It could then be reasoned that only $61 \%$ of the 
observed differences in laying rates derived from differences in oviposition intervals. Longer inter-sequence pauses among the dwarfs could account for an additional $6 \%$ difference in the laying rates. These findings indicate a much slower rate of follicular recruitment and maturation of the dwarf hens, agreeing with previous authors (Yoo et al., 1984). Additionally, a considerable percentage of dwarf hens in our study showed erratic times of oviposition, probably associated with internal ovulation, both reducing the rate of lay and the mean sequence length.

The values for total lag found in all genetic groups are lower than those reported by Lillpers \& Wilhelmson (1993) and also lower than those predicted by the Morris equation applied to the present sequence length (Morris, 1973; [equation 5]). The latter author showed that, for a given sequence size, total lag decreased with increasing light-dark cycles in which the light period was constant and the dark period increased. Therefore, the lower values found in this study seem to reflect the long scotoperiod to which the hens were subjected. Total lag is a measure of the proportion of the day used for egg laying and can be regarded as an indication of the length of the open period for ovulation (Fraps, 1970). A shortening of the duration of the open period may reduce the ovulation rate and hence the rate of oviposition (Robinson et al., 1990). The differences in total lag found between genotypes are then in good agreement with and probably contributed to the observed differences in laying rates.

Comparison of oviposition intervals for a given sequence length (Table 2) showed that the longer the size of the sequence the lesser the effect of the dwarf gene. Maximum difference was observed in sequences of two eggs, agreeing with the findings of Amin-Bakhche \& Mérat (1975). Mean oviposition interval decreased at an inverse proportion of the size of the string of egg laid in sequence, tending to $24 \mathrm{hr}$ in long sequences.

A bimodal pattern of distribution of oviposition intervals in dwarf hens was previously reported by Yoo et al. (1984) in birds with mean sequence length similar to that of our population. We found individual bimodal distribution of intervals in almost all dwarf hens with mean sequence length of up to four eggs, which was not present in hens with higher mean sequence length. However, bimodal distribution was also observed in the very few short sequences laid by normal sized hens. Our observations do not contradict the hypothesis stated by those authors that bimodal distribution of intervals is not of genetic origin but rather seem to indicate that the pattern shown by dwarf hens is closely related with their mean sequence size.

The positive correlation between oviposition interval and time of oviposition suggests that hens with short intervals laid their eggs earlier in the day than hens with longer intervals. Intra-sequence intervals were also positively correlated with inter-sequence pauses and negatively correlated with egg number. The relationships between these traits suggest that hens with short intervals, which in turn are more prolific, have higher rates of follicular recruitment and maturation. A significant negative correlation between oviposition interval and egg weight was found solely in naked neck normal size hens. Further investigation revealed that the correlation between egg number and egg weight was positive and moderate in that particular genetic group while negative and low in the remaining three. This indicates that it would be possible to find prolific naked neck non-dwarf hens whose eggs are laid with short intervals, but are, nonetheless, very heavy. The negative phenotypic correlation between oviposition interval and egg mass found by Lillpers \& Wilhelmson (1993) favours this suggestion.

The gradual decrease of yolk and egg weight throughout the sequence reported by previous authors (Lillpers \& Wilhelmson, 1993) was confirmed in the present work for all genotypes except the naked neck normal size. In this group of hens, not only was weight of the yolk apparently unrelated to its position within the sequence but also egg weight slightly increased as indicated by the positive though non-significant regression coefficient. This suggests a more stable yolk formation and, therefore, could be one underlying factor of their higher yolk weight per unit of egg (Garcês, 2000). The higher rate of decline of egg weight within the sequence observed in dwarf hens in comparison with their normal size counterparts suggests a less active yolk formation, as stated previously by Mérat (1971).

Eggs laid by the genotypes studied revealed similarities and differences in their characteristics. The reduced albumen height of dwarfs agrees with Mukherjee et al. (1986). However, the poorer quality of the thick albumen in hens carrying the $N a$ gene, more evident among the normal sized, is quite surprising, as it was reported by those authors in a lightweight rather than a medium heavy layer strain. 


\section{References}

Amin-Bakhche, M. \& Mérat, P., 1975. Étude d'un gène de nanisme lié au sexe chez la poule: heure de ponte et caractéristiques des œufs successifs dans la série de ponte. Annales de Génétique et Sélection animale 7, 13-22.

Fraps, R.M., 1970. Photoregulation in the ovulation cycle of the domestic fowl. In La photorégulation de la reproduction chez les oiseaux et les mammifères. Eds. Benoit, J. \& Assenmacher, I. Colloques Internationaux. Centre National de la Recherche Scientifique, No. 172., 281-306.

Garcês, A., 2000. The efficiency of tropical relevant major genes in a dual purpose layer strain in the subtropical coastal region of south-east Africa. PhD thesis. University of Pretoria, South Africa.

Garcês, A., Casey, N.H. \& Horst, P., 2001. Productive performance of naked neck $(\mathrm{Na})$, frizzle $(F)$ and dwarf $(d w)$ laying hens under the climatic conditions of the tropical coastal plain of south-east Africa and two nutritional treatments. S. Afr. J. Anim. Sci. 31, 174-180.

Horst, P. \& Petersen, J., 1981. The effect of the dwarf gene on the adaptability of laying hens to high environmental temperatures. Anim. Res. Develop. 13, 69-74.

Horst, P. \& Rauen, H.W., 1986. Significance of the naked-neck (Na-gene) in poultry breeding in the tropics. Proc. $7^{\text {th }}$ Eur. Poult. Conf., Paris, 191-195.

Katangole, J.B.D., Ochetim, S. \& Horst, P., 1990. Effect of dwarf $(d w)$ and naked neck $(N a)$ genes on performance of layers under Zambian conditions. Zambian J. Agric. Sci. 1, 30-39.

Lillpers, K. \& Wilhelmson, M., 1993. Genetic and phenotypic parameters for oviposition pattern traits in three selection lines of laying hens. Br. Poult. Sci. 34, 297-308.

Mérat, P., 1971. Influence of the dw gene on egg laying and egg quality traits. World's Poult. Sci. J. 27, 282.

Mérat, P., 1972. Quelques effets du gène dw sur la ponte et sur la qualité des œufs. Ann. Génét. Sél. anim. 4, 217-220.

Mérat, P., 1990. Pleiotropic and associated effects of major genes. In: Poultry Breeding and Genetics. Ed. Crawford, R.D.. Elsevier, Amsterdam, The Netherlands.

Meyer, G.E., 1993. SPSS. A minimalist approach. Harcourt Brace Jovanovich College Publishers, Orland, USA.

Morris, T.R., 1973. The effects of ahemeral light and dark cycles on egg production in the fowl. Poult. Sci. $52,423-455$.

Mukherjee, T.K., Panandam, J.M. \& Horst, P., 1986. Effect of the sex-linked dwarf $(d w)$ and naked neck (Na) genes on quantitative traits. Malays. Appl. Biol. 15, 65-77.

Reddy, P.R.K. \& Seigel, P.B., 1977. Selection of body weight at 8 weeks of age. 14. Effect of sex-linked gene. Poult. Sci. 56, 1004-1008

Robinson, F.E., Hardin, R.T. \& Robblee, A.R., 1990. Reproductive senescence in domestic fowl: Effects on egg production, sequence length and inter-sequence pause length. Br. Poult. Sci. 31, 871-876.

Yoo, B.H., Sheldon, B.L. \& Podger, R.N., 1984. Increase in oviposition interval due to the sex-linked dwarf gene in White Leghorns and Australorps. Br. Poult. Sci. 25, 119-126. 